Hispania Sacra, LXIV Extra I, enero-junio 2012, 179-203, e-ISSN: 1988-4265

doi: $10.3989 / \mathrm{hs} .2012 .029$

\title{
LA LEY DE CONFESIONES Y CONGREGACIONES RELIGIOSAS DE 1933 Y LA FUNDACIÓN DE LAS DESCALZAS REALES DE MADRID
}

\author{
POR \\ JUSTO POLO SERRANO \\ Archivo General del Ministerio de Justicia \\ KAREN M ${ }^{\mathrm{a}}$ VILACOBA RAMOS \\ Universidad Nacional de Educación a Distancia \\ $M^{\text {a }}$ TERESA MUÑOZ SERRULLA \\ Universidad Complutense de Madrid
}

\begin{abstract}
RESUMEN: El objetivo principal de este trabajo es aportar información sobre el Monasterio de Descalzas Reales de Madrid en la primera mitad del siglo XX por medio del análisis del expediente que se formó en 1933 a raíz de la ley de Confesiones y Congregaciones religiosas, y muy especialmente dar noticia del fondo que se formó con toda la documentación que los diferentes institutos religiosos debieron presentar para conseguir su inclusión en el registro que les permitiría subsistir.
\end{abstract}

PALABRAS CLAVE: Ley de Confesiones y Congregaciones Religiosas, 1933, Descalzas Reales, Madrid, Fuentes.

\section{THE LAW OF CONFESSIONS AND RELIGIOUS CONGREGATIONS, 1933, AND THE MONASTERY OF THE ROYAL BAREFOOTED NUNS IN MADRID}

\begin{abstract}
The principal aim of this work is to provide information about the Monastery of the Royal Barefooted Nuns in Madrid during the first half of the 20th century by means of the analysis of the process that was formed in 1933 immediately after the law of Confessions and Religious Congregations, and specially to provide news about the documentary file that was formed with all the documents that the different religious institutes had to present to obtain their incorporation in the Registry that would allow them to survive.
\end{abstract}

KEYS WORDS: Law of Confessions and Religious Congregations, 1933, Descalzas Reales, Royal Barefooted, Madrid, Sources.

Recibido/Received 2011-07-01

Aceptado/Accepted 2011-10-03

El Monasterio de las Descalzas Reales de Madrid tuvo, a lo largo de su rica historia, momentos de grandeza y trascendencia en el devenir de la Monarquía hispánica así como momentos de graves dificultades que hicieron peligrar su continuidad. Entre estos últimos, el período inmediatamente 
anterior a la guerra civil española marcaría de forma determinante su propia evolución. La Ley de Confesiones y Congregaciones Religiosas de

1933, al igual que para otras instituciones religiosas, supuso un momento clave en su historia. El análisis de la documentación generada con motivo de esta normativa, nos permite profundizar en el conocimiento de la historia de las Descalzas Reales, en una época que a diferencia de la moderna tiene pocos estudios.

El objetivo principal de este trabajo es aportar información sobre este Monasterio en dicho momento histórico por medio del análisis del expediente que se formó en 1933 a raíz de la mencionada ley y muy especialmente dar noticia del fondo que se formó con toda la documentación que los diferentes institutos religiosos debieron presentar para conseguir su inclusión en el registro que les permitiría subsistir.

\section{BREVE RESEÑA HISTÓRICA}

El monasterio de las Descalzas Reales comienza su andadura gracias a la iniciativa de doña Juana de Austria, hermana de Felipe II, quien en 1559 cristaliza todos sus ideales espirituales en la fundación de un monasterio. En 1558 Francisco de Borja enviaba desde el convento de Clarisas de Gandía una comunidad de monjas para el nuevo cenobio. El día de la Asunción de 1559 se hizo una solemne inauguración del monasterio, aunque para verlo terminado de forma definitiva habría que esperar hasta 1564 ya que la iglesia del recinto claustral estaba aún sin construir. En dicho año se terminaron las obras y se colocó el Santísimo Sacramento en el altar mayor.

A lo largo de los siglos modernos, especialmente la segunda mitad del siglo XVI y el siglo XVII, el monasterio cobró una importancia relevante tanto a nivel político como social, el ingreso de monjas de la dinastía de los Austrias y de la aristocracia más destacada de la época hizo que la influencia del cenobio aumentara. Muestra de la relevancia que llegó a adquirir es la gran colección de obras de arte que reunió fruto de las múltiples donaciones de los más importantes miembros de la alta sociedad.

Durante la Guerra Civil ${ }^{1}$ la comunidad tuvo que abandonar el monasterio produciéndose la exclaustración de todas las religiosas que pudieron poner a buen recaudo la mayoría de las obras de arte, bien enviándolas fuera de España o bien escondiéndolas en domicilios particulares de los devotos. No sólo el rigor de la guerra civil se dejó notar en la exclaustración de la comunidad sino también en el edificio conventual, que sufrió algunos desperfectos.

\section{LEY DE CONFESIONES Y CONGREGACIONES RELIGIOSAS DE 1933}

La ley de Confesiones queda enmarcada durante la Segunda República, cuyo uno de sus objetivos fue crear un Estado laico. La reforma religiosa se centró en cuatro puntos: secularización de los usos

1 Muñoz Serrulla, Ma T; Vilacoba Ramos, K Ma, y Sanz de Bremond Mayáns, A. 2008. "Exclaustraciones en las Descalzas Reales: Supervivencia de una Fundación Real en la primera mitad del siglo XX” en Peláez del Rosal, M. (dir., y ed.), El franciscanismo en Andalucía. Exclaustraciones y desamortización de los conventos franciscanos andaluces: 175-196. Córdoba: Córdoba, Asociación Hispánica de Estudios Franciscanos. XIII Curso de Verano sobre "El Franciscanismo en Andalucía” 24-27 de Julio de 2007. 
sociales; control estatal sobre las actividades de las asociaciones religiosas; reversión al patrimonio nacional de una aparte de los bienes eclesiásticos y la eliminación de la influencia del clero en el sistema educativo, buscando crear una escuela pública y laica. ${ }^{2}$

La Constitución de 1931 en su art. 26 lo expresa claramente, siendo el Estado el único que podría expedir títulos académicos y profesionales. Este artículo, además dejaba a las congregaciones en una situación desfavorable, al quedar sujetas a un derecho especial. Las medidas principales fueron:

- la disolución de la Compañía de Jesús por Decreto del 23 de enero de 1932, el Gobierno dio de baja a la Compañía como asociación con personalidad jurídica en España, disolvió sus comunidades y nacionalizó parte de sus bienes, especialmente colegios y residencias, que pasaron a ser administrados por un Patronato;

- el Decreto de secularización de los cementerios, firmado el 30 de enero de 1931, donde se establecía la propiedad municipal de los mismos, que hasta esa fecha, eran administrados por iglesias parroquiales o cofradías sacramentales. Los entierros católicos, como manifestaciones públicas de culto, serían regulados por las autoridades locales, que bien podrían prohibirlos, o bien gravarlos con impuestos;

- la Ley del Divorcio, de 2 de febrero de 1932, en el que se buscaba que el Estado asumiera una competencia civil que le atribuía la Constitución. Esta ley fue poco acogida por la población en general y se hizo poco uso de ella;

- y por último, la Ley de Confesiones y Congregaciones Religiosas, en las que nos detendremos.

Efectivamente el 17 de mayo de 1933 se aprobaba La ley de Confesiones y Congregaciones Religiosas, que quedaría reglamentada por Decreto del 27 de julio del mismo año, esta medida definía al Estado español como un Estado laico: "El estado no tiene religión oficial. Todas las Confesiones podrán ejercer libremente el culto dentro de sus templos: Para ejercerlo fuera de los mismos se requería la autorización especial gubernativa en cada caso". ${ }^{3}$

Esta Ley afectaba a la Iglesia, ya que se imponía la regulación de las órdenes y congregaciones religiosas, que deberían inscribirse en un Registro especial en el Ministerio de Justicia. Por otro lado, se nacionaliza parte del patrimonio eclesiástico y cualquier lugar destinado al culto religioso, aunque se le dejaba a la Iglesia el uso de los mismos para la celebración de los Oficios. El Estado se atribuía, igualmente, la potestad de vetar los nombramientos de las jerarquías eclesiásticas y, también decretaba el cierre de los centros de enseñanza de la Iglesia, con excepción de los Seminarios.

La nacionalización de los bienes de la Iglesia se materializaba en el título III del régimen de bienes de las Confesiones religiosas: "Pertenecen a la propiedad pública nacional los templos de toda clase y sus edificios anexos, los palacios episcopales y casa rectorales, con sus huertas anexas o no, seminarios, monasterios y demás edificaciones destinadas al servicio del culto católico o de sus ministros. La misma condición tendrán los muebles, ornamentos, imágenes, cuadros, vasos, joyas, telas y demás objetos de toda clase instalados en aquéllos y destinados expresa y permanentemente al culto católico, a su esplendor o a las necesidades relacionadas directamente con él". ${ }^{4}$

${ }^{2}$ Sobre este particular, Asensio Sánchez, M. A. 1999. Proceso secularizador y libertad de enseñanza en el Derecho Histórico español. Málaga: Universidad de Málaga.

${ }^{3}$ Art. 3.

${ }^{4}$ Art. 11 . 
La respuesta de las autoridades eclesiásticas a esta ley no se hizo esperar, el 3 de junio de 1933 el Papa Pío XI a través de la Encíclica Dilectissima nobis, expresaba "Y precisamente porque la gloria de España está tan íntimamente unida con la religión católica, nos sentimos doblemente apenados al presenciar las deplorables tentativas que de un tiempo a esta parte se están reiterando para arrancar a esta nación a Nos tan querida, con la fe tradicional, los más bellos títulos de grandeza nacional. No hemos dejado de hacer presente con frecuencia a los actuales gobernantes de España -según nos dictaba nuestro paternal corazón- cuán falso era el camino que seguían y de recordarles que no es hiriendo el alma del pueblo en sus más profundos y caros sentimientos como se consigue aquella concordia de los espíritus que es indispensable para la prosperidad de una nación $[\ldots]^{\prime} .5$

El cambio electoral de noviembre de 1933 supuso que se suspendiera la aplicación de la Ley de Congregaciones, con lo que la Iglesia, entre otras cosas, pudo mantener abiertos sus centros docentes.

\section{EXPEDIENTES GENERADOS POR LA LEY DE CONFESIONES}

Por lo estipulado en la Ley de Confesiones y Congregaciones religiosas, las Órdenes y Congregaciones tuvieron que conseguir su inscripción en el Registro público para continuar con sus actividades y que su existencia legal se mantuviera. Para formalizar dicha inscripción se establecía que en el plazo de tres meses se debían presentar los siguientes documentos:

- Dos ejemplares de sus Estatutos en los que se exprese la forma de gobierno tanto de sus provincias canónicas o agrupaciones monásticas asimiladas como de sus casas, residencias u otras entidades locales.

- Certificación de los fines a que se dedique el instituto religioso respectivo y la casa o residencia cuya inscripción se solicita.

- Certificación expedida por el Registro de la Propiedad de las inscripciones relativas a los edificios que la comunidad ocupe, los cuales habrán de ser de propiedad de españoles, sin que se puedan gravar ni enajenar en favor de extranjeros.

- Relación de todos los bienes inmuebles, valores mobiliarios y objetos preciosos, ya los posean directamente ya por personas interpuestas.

- Los nombres y apellidos de los superiores provinciales y locales, que habrán de ser de nacionalidad española.

- Relación de los nombres y apellidos y condición de sus miembros, expresando los que ejerzan cargo administrativo, de gobierno o de representación. Dos tercios, por lo menos, de los miembros de la Orden o Congregación habrán de tener nacionalidad española.

- Declaración de los bienes aportados a la comunidad por cada uno de sus miembros. Las alteraciones que se produzcan en relación con los anteriores extremos se pondrán en conocimiento del Ministerio de Justicia en el término de cincuenta días.

A partir de estas instrucciones se empieza a recibir la documentación requerida de las Órdenes y Congregaciones y por tanto a formarse el fondo objeto de este estudio.

\footnotetext{
${ }^{5}$ Título 2.
} 


\section{DESCALZAS REALES DE MADRID}

El expediente de las Descalzas Reales de Madrid ${ }^{6}$ se abre con la minuta por medio de la cual la Sección $2^{\mathrm{a}}$ de las Subsecretaría del Ministerio de Justicia comunica a la comunidad el 25 de junio de 1935 su inscripción en el libro de Registro correspondiente con el número 3.219.

Los siguientes documentos son los presentados en su momento por las Descalzas Reales para lograr dicha inscripción.

La abadesa de la comunidad" de "Descalzas de Santa Clara, establecida en la Plaza de las Descalzas, número 3, de esta Villa de Madrid y perteneciente a la Orden de Santa Clara, aprobada por el Sumo Pontífice Inocencio IV, el día nueve de Agosto de 1253 y reconocida por Real Cédula de 15 de Octubre de 1602 por el Rey Felipe III" presenta la documentación requerida. Dentro de la instancia se resume la información demandada y adjunta como anexos los documentos demandados.

En la misma solicitud se incluye la información referida a la composición de la comunidad:

Religiosas de Coro de Votos Solemnes:

- Encarnación Gayo Bardo, Abadesa, natural de Monterizo, provincia de Oviedo.

- Valentina López Lineres, Vicaria, natural del Moral de Calatrava, provincia de Ciudad Real. ${ }^{8}$

- María Jordán Tardio, Consejera, natural de Abiego (Huesca). ${ }^{9}$

- Rosario Suay Dagues, Consejera, natural de Valencia. ${ }^{10}$

- Asunción Calvo Claver, Consejera, natural de Abiego (Huesca). ${ }^{11}$

- Dominica Egües Orbaiz, Ecónomo, natural de Arre (Navarra). ${ }^{12}$

- Angeles Alzuru Alzuru, Secretaria, natural de Zarauz (Guipúzcoa). ${ }^{13}$

Religiosas Profesas Solemnes y de Coro

- María Remiro Gómara, natural de Cascante (Navarra). ${ }^{14}$

- Petra Mur Jordán, natural de Abiego (Huesca). ${ }^{15}$

- Quintina Eransus Equiza, natural de Mendioroz (Navarra). ${ }^{16}$

- Antonia María Solo de Zaldivar y de Medina, natural de Don Benito (Badajoz). ${ }^{17}$

${ }^{6}$ Archivo General del Ministerio de Justicia (AGMJ). Eclesiástico, Leg. 167, Exp. 3.219, Congregación de Religiosas Descalzas de Santa Clara de Madrid. El número de expediente coincide con el número con que se inscriben las congregaciones en el libro Registro correspondiente, de forma que el fondo queda compuesto por aquellos expedientes de las congregaciones que justificaron la documentación y condiciones exigidas por la ley y que por tanto lograron su inscripción.

${ }^{7}$ Doña Encarnación Gayo Bardo profesó con el nombre de Sor María Anunciación y fue abadesa entre los años 1925 a 1928 y 1931 a 1939. Vilacoba Ramos, K Ma y Muñoz Serrulla, Ma T. 2010: "Las Religiosas de las Descalzas Reales de Madrid en los siglos XVI-XX: Fuentes archivísticas”, Hispania Sacra, LXII/125: 153.

${ }^{8}$ Sor María Valentina de los Ángeles, fue abadesa entre 1916-1919 y 1928-1931. (Ibídem, p. 149).

${ }^{9}$ Sor María Bernardina de Santa Margarita. (Ibidem, p. 148).

${ }^{10}$ Sor María Rosario de San Antonio. (Ibídem, p. 151).

${ }^{11}$ Sor María Asunción de la Ascensión. (Ibídem, p. 152).

12 Sor Dominica de San José. (Ídem).

${ }^{13}$ Sor María de los Dolores. (Ídem).

${ }^{14}$ Sor María Visitación. (Ibídem, p. 150).

${ }^{15}$ Sor Petra de la Purificación, fue abadesa entre 1939-1946 y 1953-1956. (Ibídem, p. 154).

${ }^{16}$ Sor María Francisca. (Ibídem, p. 153).

${ }^{17}$ Sor María de Santa Clara. (Ibídem, p. 155). 
- Mercedes Castillo Valdés, natural de Madrid. ${ }^{18}$

- Dolores Galdona Echave, natural de Tolosa (Guipúzcoa). ${ }^{19}$

- Concepción Foz Bernardo de Quirós, natural de Alcañiz (Teruel). ${ }^{20}$

- Inés Rezabal Zuloaga, natural de Aizarna Cestona (Guipúzcoa). ${ }^{21}$

- Juliana Macarrón Penacho, natural de Pedraja de San Esteban (Soria). ${ }^{22}$

- Apolonia Moreno Layos, natural de Consuegra (Toledo). ${ }^{23}$

- Natividad Seco Clérigo, natural de Villadiego (Burgos). ${ }^{24}$

Religiosas Legas de Votos Solemnes

- Martina Taravilla Sanz, natural de Priego (Cuenca). ${ }^{25}$

- Felipa García Aragón, natural de Aguilafuente (Segovia). ${ }^{26}$

- Marcelina Urriza Zenoz, natural de Alcoz (Navarra). ${ }^{27}$

- Josefa Leoz Portilo, natural de Leoz, (Navarra). ${ }^{28}$

- María Galdeano Sotés, natural de Ereaul (Navarra). ${ }^{29}$

Religiosas de Votos Temporales de Coro

- Ángeles Siboni Guillén, natural de Madrid. ${ }^{30}$

Religiosas Novicias de Coro

- Natalia del Amo Guerrero, natural de Madrid. ${ }^{31}$

Posteriormente, la información aportada tiene que ver con los bienes que declara poseer la comunidad, "Esta comunidad no posee por si, ni por persona interpuesta más bienes inmuebles, valores mobiliarios ni otra clase ni objetos preciosos que los que a continuación se expresan". ${ }^{32}$ Como bienes inmuebles se incluye: "El Convento con su huerta, iglesia y casas de la dependencia, todo de la propiedad de la Fundación de Doña Juana de Austria, Administrada por el Ministerio de la Gobernación. No se cobra ninguna renta y está en buen estado de conservación". ${ }^{33}$ Sobre este particular se anexa la certificación del Registro de la Propiedad donde se detalla dicha información, documento que además era obligatorio presentar para lograr la inscripción de la comunidad en el nuevo libro de registro. $^{34}$

${ }^{18}$ Sor María de la Presentación. (Ibídem, p. 152).

${ }^{19}$ Sor María del Sagrado Corazón de Jesús. (Ibídem, p. 154).

${ }^{20}$ Sor María de la Concepción de la Santísima Trinidad. (Ibidem, p. 153).

${ }^{21}$ Sor María del Santísimo Sacramento. (Ibídem, p. 155).

${ }^{22}$ Sor María Juliana de la Inmaculada. (Ibidem, p. 154).

${ }^{23}$ Sor María Juana de la Cruz, fue abadesa entre 1946-1953 y 1956-1970. (Ibídem, p. 152).

${ }^{24}$ Sor María Natividad del Niño Jesús. (Ibídem, p. 155).

${ }^{25}$ Sor Martina de la Encarnación. (Ibidem, p. 151).

${ }^{26}$ Sor Felipa María de la Asunción. (Ibídem, p. 147).

${ }^{27}$ Sor María Marcelina de la Esperanza. (Ibídem, p. 156).

${ }^{28}$ Sor María Josefa del Pilar. (Ibídem, p. 154).

${ }^{29}$ Sor María del Milagro de la Sagrada Familia. (Ibídem, p. 153).

${ }^{30}$ Sor María Ángeles de Teresa de Jesús. (Ibídem, p. 156).

${ }^{31}$ Sor María de Jesús. (Ibídem, p. 152).

${ }^{32}$ AGMJ. Eclesiástico, Leg. 167, Exp. 3.219. Instancia, p. 4.

${ }^{33}$ Ídem.

${ }^{34}$ Ídem. Certificación del Registro de la Propiedad 21 de agosto de 1933, se adjunta copia simple del mismo documento. Previa a la certificación se conserva la solicitud del capellán mayor D. José García de Armesto para obtener dicha certificación (14 de agosto de 1933). 
En lo que se refiere a los bienes, mobiliarios la comunidad declara que a fecha de 14 de septiembre de 1933 son:

- En Títulos de la Deuda Perpetua interior, 291.300 Ptas.

- En un Título de Deuda Amortizable, 5.000 Ptas.

Los siguientes datos tienen que ver con las aportaciones recibidas por la comunidad de parte de las religiosas, es decir, las dotes entregadas en el momento de su ingreso en el Monasterio:

- Encarnación Gayo Bardo, 2.500

- Valentina López Linares, 4.250

- María Jordán Tardio, 2.000

- Rosario Suay Dagues, 4.500

- Asunción Calvo Claver, 2.250

- Dominica Egues Orbaiz, 5.000

- Angeles Alzuru Alzuru, 3.000

- María Remiro Gómara, 5.850

- Petra Mur Jordán, 2.500

- Quintina Eransus Equiza, 4.500

- Antonia María Solo de Zaldivar y de Medina, 5.000

- Mercedes Castillo Valdés, 4.600

- Dolores Galdona Echave, 4.500

- Concepción Foz Bernardo de Quirós, 3.000

- Inés Rezabal Zuloaga, 1.000

- Juliana Macarrós Penacho, 3.090

- Apolonia Moreno Layos, 1.000

- Natividad Seco Clérigo, 3.000

- Martina Taravilla Sanz, 1.500

- Felipa García Aragón, 1.000

- Marcelina Urriza Zenoz, 1.750

- Josefa Leoz Portillo, 2.500

- María Galdeano Sotés, 2.000

- Angeles Siboni Guillén, $5.000^{35}$

En lo que se refiere a las mandas se citan:

- 2.100 pesetas nominales con obligación de levantar cargas.

- 5.000 pesetas nominales, con obligación de levantar cargas.

- 4.700 pesetas entregadas por una señora con obligación de algunos sufragios. ${ }^{36}$

Por último, se hace mención a los objetos preciosos que no se relacionan por haber inventario en el Ministerio de la Gobernación, al cual remite la comunidad.

${ }^{35}$ Se hace la aclaración en la instancia sobre la aportación de esta última religiosa cuya cantidad (5.000 ptas.), es la cantidad amortizable referida anteriormente, mientras que el resto de las dotes están incluidas en la Deuda Perpetua interior.

${ }^{36}$ AGMJ. Eclesiástico, Leg. 167, Exp. 3.219. Instancia, p. 7. 
El último documento que se adjunta a la instancia es la copia de los estatutos por los que se rige la comunidad. Este aspecto se verá con más detalle en el siguiente apartado.

ESTATUTOS DE LAS DESCALZAS REALES, 1933.

La normativa incluida en el expediente objeto de análisis, se compone de 8 títulos y 37 artículos. Sorprende su brevedad si se compara con otras normativas anteriores, sin ir más lejos, con los estatutos de 1930, que se componían de 148 artículos y 8 normas adicionales de previsión.

Los estatutos de 1930 son fruto del trabajo llevado a cabo por el capellán mayor de las Descalzas, D. José García de Armesto (el mismo capellán que tramita el expediente en el Ministerio de Justicia). Se trata de una edición de cuya entrada en vigor no tenemos constancia, de hecho, si atendemos a la información que nos ofrecen los propios estatutos junto con otra conservada en el Archivo General de Palacio, debemos pensar que esta normativa no llegó a regir la vida de la Fundación.

La copia manejada se publicó en $1930,{ }^{37}$ y tras un breve estudio introductorio en el que se reseña la evolución histórica de la Fundación ${ }^{38}$ y se describe su estructura orgánica, ${ }^{39}$ se pasa a argumentar la necesidad de unas nuevas constituciones para las Descalzas. Obviamente la adecuación a los nuevos tiempos se presenta como la necesidad principal, pero estas nuevas necesidades se ven directamente relacionadas con cuestiones económicas.

La documentación conservada en el Archivo General de Palacio nos muestra como desde $1929^{40}$ el capellán mayor llevó a cabo una labor fundamental relacionada con estos aspectos y, que al parecer no se vio culminada como él hubiera querido. El expediente, en cuestión se forma con varios informes de diferentes fundaciones dotadas en las Descalzas, en concreto, las de Sor Ana Dorotea, Fernando de Borja, Diego de Durbarán y Laura Tedaldi. Dichas fundaciones fueron dotadas en su momento con diferentes rentas (juros) que debían actualizarse, convirtiéndolas finalmente en Deuda Pública interior. Unida a esta labor, García de Armesto insiste en la necesidad de dotar a las Descalzas Reales de unas nuevas constituciones, sin embargo, este aspecto que debía contar con el visto bueno del visitador, se vio paralizado, y aunque el capellán recurrió a diferentes instancias, no consta su aprobación.

Unido a esto, sabemos por otro documento (Crónica del Monasterio de las Descalzas Reales) ${ }^{41}$ redactado por las propias religiosas, que en 1931 la situación del Monasterio se vio alterada de forma

${ }^{37}$ García de Armesto, J. 1930. Nuevas Constituciones de la Real Fundación de la Capilla y Monasterio de las Descalzas de Madrid. Madrid: Editado por Senén Martin Díaz.

${ }^{38}$ El autor divide dicha trayectoria en tres etapas a las que denomina: de normalidad; de anormalidad por ataques sectarios; y de restauración, dividida a su vez en otras tres etapas.

${ }^{39}$ El capellán mayor presenta los Órganos Directivos, compuestos en primer lugar por la Abadesa cuya autoridad se subordina al General de la Orden, y en segundo lugar por el Capellán Mayor. Los Órganos Judiciales / Inspectores formados por los visitadores ordinarios y extraordinarios y por último el Órgano Ejecutivo o lo que es lo mismo el Capellán Mayor.

${ }^{40}$ Archivo General de Palacio (AGP), Patronatos, Descalzas Reales, Leg. 33, Exp. 1. Los documentos reunidos en este expediente no presentan una buena conservación, por lo que hay parte de la información que se pierde.

${ }^{41}$ AGP, Patronatos, Descalzas Reales, Leg. 17, Exp. 1. Crónica del Monasterio de las Descalzas Reales. S. f. Esta crónica recogida por las propias religiosas se extiende desde 1931 hasta la década de los 90 . Si bien el detalle comienza desde 1936, las primeras páginas resumen brevemente la situación anterior.

Hispania Sacra, LXIV, Extra I, enero-junio 2012, 179-203, e-ISSN: 1988-4265, doi: 10.3989/hs.2012.029 
importante por lo que la cuestión de los estatutos debió quedar en segundo plano. Con la instauración de la I República, las religiosas estaban preparadas para tener que abandonar el monasterio en cualquier momento: "Familiares y conocidos de la Comunidad habían proveido a las religiosas de vestidos seglares, pues claramente se adivinaba, no tardarían en verse obligadas a abandonar precipitadamente el Monasterio a fin de librarse del encono de los elementos revolucionarios". 42 Poco después, la exclaustración forzosa llegó el 11 de mayo de $1931{ }^{43}$

Por tanto, los estatutos de las Descalzas, debieron prepararse y resumirse para su entrega en 1933. Estudiado el documento que se adjunta con la instancia parece bastante obvio que existió un modelo o similar por el que las congregaciones fueron ajustando sus estatutos. El contenido es el siguiente:

\section{ESTATUTOS DE LA COMUNIDAD DE RELIGIOSAS CLARISAS ESTABLECIDA EN MADRID: ${ }^{44}$}

Título I. Constitución, Denominación y Domicilio.

Art. $1^{\circ}$. Al amparo de la Constitución y de la Ley especial de Confesiones y Congregaciones religiosas se constituye en Madrid, una Comunidad de Religiosas de la Orden de Santa Clara, aprobada por el Sumo Pontífice Inocencio IV con su Bula "Solet Annuere" el día 9 de Agosto del año 1253 y existente desde entonces en España.

Art. $2^{\circ}$. Para todos los efectos legales, la Comunidad se regirá por los presentes Estatutos y con arreglo a las leyes vigentes.

Art. $3^{\circ}$. La Comunidad al reconstituirse tiene su domicilio social en la Plaza de las Descalzas, número tres y aquí celebra sus reuniones de régimen interno.

Título II. Fines de la Comunidad y de su Instituto

Art. $4^{\circ}$. El fin de la Comunidad es el general de la Orden y principalmente el culto divino, la santificación de sus miembros y la salvación de los prójimos, valiéndose al efecto de la observancia de los tres votos públicos de pobreza, castidad y obediencia, de la perfecta vida común y de la práctica de las virtudes.

Art. $5^{\circ}$. Esta Comunidad que tiene por objeto principal el culto divino, no excluye las obras de la caridad y de apostolado compatibles con esta sagrada obligación, ni mucho menos la formación integral de sus miembros, ni la enseñanza oportuna de la religión, ni otras obras de misericordia espirituales y corporales, según sus recursos.

Art. $6^{\circ}$. Esta Comunidad puede admitir externados y pensionados para la educación extra académica, religiosa y doméstica, excluida toda mira de lucro.

Art. $7^{\circ}$. De los fines de la Comunidad queda excluida toda actividad política, industrial, comercial, agrícola y docente de la colectividad.

Título III.- Miembros y Gobierno de la Comunidad

${ }^{42}$ Ibidem, p. 1.

${ }^{43}$ Ibidem, pp. 2-5.

${ }^{44}$ AGMJ. Eclesiástico, Leg. 167, Exp. 3.219. Copia mecanografiada de 4 páginas, firmada en Madrid a 14 de septiembre de 1933. 
Art. $8^{\circ}$. La Comunidad consta de religiosas de coro y hermanas legas o de obediencia, correspondiendo los cargos a las primeras y los oficios y quehaceres domésticos a las segundas, sin salario unas y otras.

Art. $9^{\circ}$. La entrada, permanencia y salida de los miembros se sujeta a las normas de los cánones, siendo necesaria la admisión por parte de los Superiores, su dispensa para la salida sin votos y las formalidades del Reglamento de régimen interno para la expulsión. Queda a la conciencia de las personas la perseverancia en la Comunidad.

Art. $10^{\circ}$. Los miembros de la Comunidad conservan todos sus derechos civiles y políticos, aun después de la profesión religiosa y por lo tanto la propiedad de sus bienes de cualquier clase que sean, salvo lo dispuesto en las leyes o en el Reglamento de régimen interno.

Art. $11^{\circ}$. La Comunidad es independiente en su régimen interno.

Art. $12^{\circ}$. La Comunidad se gobierna y administra legalmente por la Superiora y sus Consejeras.

Art. 13․ El Consejo de Gobierno local de la Comunidad se compone de la Superiora como Presidenta, de las Consejeras, Secretaria y Procuradora, pero el cargo de Consejera no es compatible con el de Secretaria y Procuradora. Ayudan al Gobierno local, sin cargo de Superioridad ni representación, todas las encargadas de las oficinas y dependencias de la Casa.

Art. $14^{\circ}$. Los cargos predichos se proveen en Capítulo por mayoría de votos de las Religiosas, que según el Reglamento de régimen interno, tienen derecho a intervenir.

Art. $15^{\circ}$. La Comunidad respeta y acata la jurisdicción del Ordinario Diocesano y recibe la autoridad y visita del mismo.

Art. 16 $6^{\circ}$ La Abadesa con su Consejo, trata los asuntos económicos y administrativos de importancia para la Casa, pudiendo dictar los Reglamentos oportunos para el bien espiritual y material de sus miembros.

Art. $17^{\circ}$. Los Capítulos electivos se reúnen cada tres años para tratar de la renovación de los cargos de la Comunidad, incluso el de Superiora. Todos los cargos se renuevan en dicho periodo, pero se admite la reelección.

Art. $18^{\circ}$. Los Capítulos no electivos, se reúnen por lo menos cada mes a discreción de la Superiora, con asistencia de sus Consejeras, Secretaria y Procuradora. En estos Capítulos tienen voz y voto la Superiora y las Consejeras.

Art. $19^{\circ}$. Vacante el cargo de Superiora de la Comunidad, automáticamente la sustituye la ViceSuperiora, hasta que el Capítulo extraordinario prevea de nueva Superiora.

Art. 20 ${ }^{\circ}$. La Superiora y su Consejo nombran todos los oficios secundarios de la Casa y administran sus bienes según las leyes. Cada mes se presentarán las liquidaciones y alteraciones del material a la aprobación del Consejo, los balances e inventarios anuales, antes de remitirlos al Gobierno civil y los trienales antes de enviarlos al Ministerio de Justicia.

Art. 21 ${ }^{\circ}$. La Superiora autorizará con su Visto Bueno, todas las certificaciones y relaciones exigidas por las leyes y expedidas por la Secretaria, sobre las personas o la Procuradora sobre los bienes y sobre cualquier alteración de los estados del personal y material.

Título IV.- Capacidad Jurídica

Art. $22^{\circ}$. La Comunidad tiene capacidad para adquirir, enajenar, poseer y administrar, toda clase de bienes y derechos por cualquier título oneroso o gratuito, por actos inter vivos o mortis causa y para ceder, enajenar, vender, arrendar, permutar, pignorar, hipotecar sus bienes o prestar con hipoteca u otra garantía, aceptar o renunciar legados, reclamar intereses, rentas o frutos y en general, ejercer cualquier otro derecho y celebrar toda clase de actos y contratos que las leyes reconozcan a las personas jurídicas y sean necesarias para el mantenimiento de sus miembros, el sostenimiento del culto y el cumplimiento directo de todos los fines generales y privativos de la Comunidad, expresados en el Título II. 
Art. $23^{\circ}$. La Superiora con su Consejo, podrá celebrar los actos y contratos a que se refiere el artículo anterior y también delegar todos los derechos y acciones que haya de ejercer ante los Juzgados y Tribunales y ante toda clase de autoridades competentes, tanto en el orden civil, como en el económico administrativo y contencioso administrativo, por cualquier concepto que sea.

Art. $24^{\circ}$. La Procuradora o la persona delegada, previa la delegación o mandato a que se refiere el artículo anterior, podrá en representación de la Comunidad y de sus miembros, presentarse en todos los actos, juicios y expedientes que interesen a los mismos y proseguirlos en todos los trámites, recursos e incidentes hasta su terminación definitiva y así también reclamar y cobrar todas las cantidades que en concepto de intereses, rentas o frutos correspondan a sus representados, pudiendo firmar los correspondientes recibos, cartas de pago y demás documentos que proceda.

Art. $25^{\circ}$. La gestión económica ordinaria corresponde a la Procuradora de la Comunidad, pero debe ejercitarla a tenor de las leyes y según las normas del Reglamento de régimen interno y sólo mientras dure el cargo.

Título V.- Sostenimiento de la Comunidad

Art. $26^{\circ}$. Los medios con que la Comunidad cuenta para su sostenimiento, para el cumplimiento de sus fines y para la formación de sus miembros, son todos los permitidos por las leyes y los que los ministerios de la Comunidad produzcan.

Art. $27^{\circ}$. Entre dichos medios económicos se cuentan las rentas o productos de los bienes o valores de la Comunidad, consentidos por las leyes, las limosnas, los legados y donaciones mortis causa, el trabajo material, espiritual o intelectual y todo trabajo personal de sus miembros y sus aportaciones al haber social, pero ninguno de sus miembros tiene derecho alguno personal sobre los bienes de la Comunidad, sino que todo cuanto tiene es común a todos los individuos, con la única excepción del dominio radical de los bienes patrimoniales y de los dotales durante la vida, que conservan los miembros de la Comunidad, como las demás garantías individuales que la ley civil establece y reconoce.

Art. 28 $8^{\circ}$ Los ingresos de la Comunidad deberán ser aplicados a sus gastos ordinarios, extraordinarios, imprevistos o eventuales, debiendo figurar en los balances mensuales del libro oficial de la contabilidad y en los balances generales que cada año se remiten al Gobierno civil de la Provincia y cada trienio al Ministerio de Justicia.

Art. $29^{\circ}$. En consecuencia, ni las Religiosas, ni sus parientes, herederos o causahabientes, tendrán derecho a reclamar participación alguna en los fondos sociales, exceptuando las aportaciones o cesiones hechas con la condición de reclamarlas, en el caso de abandono de la Comunidad.

Art. $30^{\circ}$. El fondo social será siempre propiedad de la Comunidad y será administrado por la Superiora y la Superiora y la Procuradora, según el Reglamento de régimen interno que se diera la misma Comunidad.

Título VI.- Representación Legal

Art. $31^{\circ}$. La Superiora de la Comunidad y en su defecto la Vice-Superiora o la Procuradora en su ramo, es su representación legal y fuera y dentro de la misma para la defensa de sus derechos y de sus bienes y el ejercicio de sus acciones dentro y fuera de juicio en todas las esferas gubernativa, administrativa, contencioso administrativa, por actos que corresponden a la Corporación o a sus miembros como personas jurídicas o socios de la Comunidad.

Art. $32^{\circ}$. Para acreditar representación bastará el testimonio del acuerdo del Consejo de la Comunidad, refrendado por la Secretaría de la misma. Por acuerdo del mismo Consejo, podrá la Superiora delegar su representación para determinados negocios a otra persona de confianza, religiosa o seglar. Queda a salvo lo dispuesto en el artículo 24 sobre la Procuradora. 
Título VII.- Reglamento de Régimen Interno.

Art. $33^{\circ}$. Reconstituida la Comunidad conforme a los presentes Estatutos, ordenará libremente su régimen interno.

Art. $34^{\circ}$. El Reglamento de régimen interno de la Comunidad, una vez aceptado por la misma, obligará a todos los miembros, así en lo que concierne al gobierno de las personas, como en la administración de los bienes, aunque sin otra trascendencia jurídica que la compatible con las leyes.

Título VIII. Disolución de la Comunidad

Art. $35^{\circ}$. La Comunidad puede disolverse por Decreto de la Superiora con su Consejo y la anuencia de la autoridad eclesiástica.

Art. $36^{\circ}$. Los bienes que poseyere la Comunidad al disolverse, se distribuirán en la forma que determine el Reglamento de régimen interno o, en su defecto, se repartirán en partes iguales entre todos los miembros.

Art. $37^{\circ}$. Si fuere restaurada la Comunidad, suspensa o disuelta temporalmente, volverán a la misma todos los bienes y derechos que le correspondían en el estado en que se encuentren al simple requerimiento de la última Superiora o de la nueva legítimamente elegida.

\section{FUNDACIONES CREADAS A PARTIR DE LAS DESCALZAS}

El Convento de las Descalzas Reales de Madrid (Madre de Dios de la Consolación) tiene como primera comunidad una serie de religiosas procedentes del Convento de Santa Clara de Gandía, atendiendo a una predicción milagrosa según la cual, del convento de Gandía saldrían religiosas a fundar otros siete conventos (uno de ellos el de Madrid), que tendría la finalidad de extender la regla de Santa Clara por el territorio peninsular. También las religiosas de las Descalzas Reales serían protagonistas de nuevas fundaciones clarianas, en concreto cinco nuevos conventos. ${ }^{45}$

\section{Convento de Trujillo}

Sobre esta fundación las noticias son escasas, sabemos que la solicitud para su fundación parte de algunos devotos de Trujillo que en piden “(...) se les diesen algunas Religiosas del dicho convento [Descalzas Reales de Madrid] para fundar un Monasterio de la primera regla y orden de Sancta Clara (...)" ${ }^{46}$ No existe expediente en el fondo que es objeto de estudio debido a la desaparición del convento en el siglo XIX, con motivo de la desamortización.

\section{Convento de Villafranca del Bierzo,}

En 1606 salieron de las Descalzas Reales a fundar en Villafranca una nueva comunidad: Sor María de la Concepción, hija del Duque de Villafranca; y Sor María de los Ángeles que fue como vicaria, sobrina de Sor Francisca de Jesús y Francisco de Borja.

${ }^{45}$ Vilacoba Ramos, K Ma y Muñoz Serrulla, Ma T. 2009. "Fuentes documentales sobre la Obra benéfica de Doña Juana de Austria: fundaciones principales, particulares y externas de las Descalzas Reales de Madrid”, Revista AAM (Asociación de Archiveros de Madrid), 4: 54-67.

${ }^{46}$ AGP, Patronatos, Descalzas Reales, Caja 13, Exp. 10. De cómo las monjas que fueron a Trujillo no tienen el derecho de la filiación para volver. 1574. 
La Congregación de Religiosas Franciscanas Clarisas de Villafranca del Bierzo solicitó la inscripción en el registro especial del Ministerio de Justicia, siendo inscritas con el número 4.012 y siéndoles comunicada su inscripción el 5 de julio de $1935 .{ }^{47}$

En 1933 era abadesa de la comunidad D ${ }^{a}$ Concepción Sánchez Andrade, la información que incluía en su solicitud era la siguiente:

Composición de la Comunidad:

Hermanas Profesas:

- Concepción Sánchez Andrade, natural de Cimbraos, Provincia de la Coruña. Abadesa, dote de seis mil pesetas.

- Isabel Díaz Porras, natural de Páramo del Sil, provincia de León. Vicaria, dote seis mil pesetas.

- Mercedes Armesto Quiroga, natural de Berlay, provincia de Lugo. Consiliaria, dote seis mil pesetas.

- Clara Álvarez de Toledo, natural de Villafranca, provincia de León. Consiliaria, dote seis mil pesetas.

- Adela Pascual Méndez, natural de Ponferrada, provincia de León. Consiliaria, dote seis mil pesetas.

Hermanas Ayudantes Profesas:

- Concepción Barco López, natural de Villafranca, provincia de León, dote seis mil pesetas.

- Concepción Carujo Veloso, natural de San Martín de Quiroga, provincia de Lugo, dote seis mil pesetas.

- Benita Fernández García, natural de Fresnedo, provincia de León, dote seis mil pesetas.

- Eugenia Fernández García, natural de Fresnedo, provincia de León, dote seis mil pesetas.

- Carmen López Díaz, natural de Páramo del Sil, provincia de León, dote seis mil pesetas.

- Filomena Vega García, natural de Banvibre, provincia de León, dote seis mil pesetas.

- Carmen Vázquez Arias, natural de Nocedo, provincia de Lugo, dote seis mil pesetas.

- Agripina Laforet Cividanes, natural de la Guardia, provincia de Pontevedra, dote seis mil pesetas.

- Paz Núñez Rodríguez, natural de Villafranca, provincia de León, dote seis mil pesetas.

- Dolores Cabezas Arias, natural de Pola de Somiedo, provincia de Oviedo, dote seis mil pesetas.

- Joaquina Henares Tijero, natural de Colmenares, provincia de Palencia, dote seis mil pesetas.

- Luz García Fernández, natural de Pola de Lena, provincia de Oviedo, dote seis mil pesetas.

- Pura Ingunza Santo Domingo, natural de Vitoria, provincia de Álava, dote seis mil pesetas.

- Marcela Pasó Covelo, natural de Vigo, provincia de Pontevedra, dote seis mil pesetas.

- Ada Martínez Méndez, natural de Villafranca, provincia de León, dote seis mil pesetas.

- Ángeles Lueiro Gil, natural de Vigo, provincia de Pontevedra, dote seis mil pesetas.

- Aurelia Rodríguez Merayo, natural de Toral de los Vados, provincia de León, dote seis mil pesetas.

- Matilde Carvajal Hervón, natural de Villafranca, provincia de León, dote seis mil pesetas.

- Aurea González López, natural de Santa Eulalia, provincia de Lugo, dote seis mil pesetas.

- María Castellanos Sánchez, natural de Cacabelos, provincia de León, dote seis mil pesetas.

- Paulina Chalbaud Cardona, natural de Mérida, República de Venezuela, dote seis mil pesetas.

- María Díaz Orro, natural de la Coruña, dote seis mil pesetas.

${ }^{47}$ AGMJ. Eclesiástico, Leg. 187, Exp. 4.012.

Hispania Sacra, LXIV, Extra I, enero-junio 2012, 179-203, e-ISSN: 1988-4265, doi: 10.3989/hs.2012.029 
- Purificación Losada Losada, natural de Sobrado, provincia de Orense, dote seis mil pesetas.

- Sara Díaz Orro, natural de la Coruña, dote seis mil pesetas.

- Carmen García Pomareda, natural de Madrid, dote seis mil pesetas.

- Benigna Orallo Álvarez, natural de Páramo del Sil, provincia de León, dote dos mil pesetas.

- Manuela García González, natural de Villamartín, provincia de León, dote dos mil pesetas.

- Alejandra Pérez López, natural de San Cristóbal de Baldueza, provincia de León, dote dos mil pesetas.

- María Fernández Rodríguez, natural de San Miguel de Vidueira, provincia de Orense, dote dos mil pesetas.

- Dolores Vecino de la Fuente, natural de Navianos, provincia de León, dote dos mil pesetas.

- Francisca Cifuentes Ganado, natural de San Pedro de Zeque, provincia de Zamora, dote dos mil pesetas.

\section{Hermana Postulante}

- Julia Molina García, natural de Madrid, dote seis mil pesetas.

La Comunidad no poseía por sí misma, ni por persona interpuesta más bienes inmuebles, valores mobiliarios, ni otra clase de objetos preciosos que los siguientes:

\section{Valores Inmuebles}

- Un Monasterio, finca urbana con su huerta adjunta, sito en la plaza de la Anunciada de esta villa, con buen estado de conservación.

- Una casa de reciente construcción, que ocupa una superficie de ciento cuarenta metros cuadrados, compuesta de planta baja y principal, sita en la plaza antes dicha y unida al edificio anterior, se encuentra destinada a vivienda del capellán del Convento.

- Una huerta al sitio de la Anunciada, término de esta villa, superficie de seis áreas y sesenta y seis centiáreas, linda al este con la cerca del Convento, al sur con la huerta de Dolores González, al oeste sendero y al norte con la huerta de Manuel Fernández, estando valorada en 385 pesetas.

- Otra huerta a los mismos sitios y término, superficie de un área cincuenta y cinco centiáreas, que linda al este con la tapia del Convento, al oeste con un camino, al norte con la finca anterior y al sur con otra de Carmen Sánchez, estando valorada en 250 pesetas.

- Otra huerta en el indicado sitio, de superficie igual a la anterior, linda al este con la tapia del Convento, al oeste con un camino, al norte con la finca anterior y al sur con otra de Josefa Sánchez, estando valorada en 250 pesetas.

\section{Valores Muebles}

La renta anual que aproximadamente percibe el Monasterio de las dotes de las religiosas, ya que éstas mientras viven conservan el dominio radical de las mismas, por un importe siete mil seiscientas ochenta pesetas (7.680 ptas).

\section{Objetos preciosos}

Solo posee los objetos ordinarios para el culto, pues no tiene ninguno precioso o que sea de gran valor.

Los Estatutos incluidos:

Estatutos de la Comunidad de Franciscanas (Clarisas) establecida en Villafranca del Bierzo, provincia de León. 
Título I. Constitución, Denominación y Domicilio.

Art. $1^{\circ}$. Al amparo de la Constitución y de la Ley especial de Confesiones y Congregaciones Religiosas, se reconstituye en la Villa de Villafranca del Bierzo, provincia de León, una Comunidad de Religiosas de la Orden Franciscanas (Clarisas) reconocida por el Concordato de 1851.

Art. $2^{\circ}$. Para todos los efectos legales, la Comunidad se regirá por los presentes Estatutos y con arreglo a las leyes vigentes.

Art. $3^{\circ}$. La Comunidad al reconstituirse, tiene su domicilio social en la Plaza de la Anunciada, número 1 y aquí celebra sus reuniones de orden interno.

Título II. Fines de la Comunidad.

Art. $4^{\circ}$. El fin de la Comunidad es la santificación de las Religiosas, mediante la guarda del Evangelio y la observancia de los votos de pobreza, castidad y obediencia, realizados en esta religión.

Art. $5^{\circ}$. Esta Comunidad que tiene por objeto principal el culto divino, no excluye las obras de caridad y de apostolado, compatibles con esta sagrada obligación, ni mucho menos la formación integral de sus miembros, ni la enseñanza oportuna de la religión, ni otras obras de misericordia, espirituales y corporales, según sus recursos.

Art. $6^{\circ}$. Excluyese de los fines sociales de la Comunidad, toda actividad política y la explotación comercial, agrícola o docente en la colectividad.

Título III. Miembros y Gobierno de la Comunidad.

Art. $7^{\circ}$. La Comunidad consta de religiosas de coro y de obediencia, correspondiendo a las coristas los cargos y a las legas los oficios y quehaceres domésticos, sin salario unas y otras.

Art. $8^{\circ}$. La entrada y salida de las socias, se ajusta a las normas de los sagrados cánones, siendo necesaria la admisión de los sujetos por parte de los superiores, la dispensa para la salida sin votos y las formalidades establecidas para las expulsiones. Queda a la conciencia de los individuos la permanencia en la Comunidad.

Art. $9^{\circ}$. Los miembros conservan todos sus derechos civiles y políticos, aún después de la profesión religiosa y por tanto la propiedad de sus bienes patrimoniales y haber hereditario y la capacidad de adquirir para sí otros de cualquier clase que sean, salvo lo dispuesto en las leyes y en el reglamento de régimen interior.

Art. $10^{\circ}$. La presente Comunidad es independiente en su régimen interno.

Art. $11^{\circ}$. La Comunidad se gobierna y administra legalmente por la Abadesa y su Discretorio.

Art. $12^{\circ}$. El Discretorio o Gobierno local de la Comunidad, se compone de la Abadesa, como Presidente, cuatro Consultoras o Discretas, de Secretaria y Ecónoma o Procuradora, pero el cargo de Consultora no es incompatible con el de Secretaria ni de Procuradora.

Art. $13^{\circ}$. Los cargos de Abadesa y Discretas se proveen por mayoría absoluta de votos de sus individuos coristas de la Comunidad, los otros por la Abadesa y Discretas.

Art. $14^{\circ}$. El Gobierno de la Comunidad respeta y acata la jurisdicción del Ordinario diocesano.

Art. 15 . La Comunidad trata en Capítulo los asuntos económicos y administrativos de importancia para la casa, pudiendo dictar los reglamentos oportunos para su régimen interior y el bien espiritual y material de sus miembros.

Art. $16^{\circ}$. El Capítulo conventual para las elecciones se reúne cada tres años para tratar de la renovación de los cargos de la Comunidad. En dicho Capítulo tienen voz y voto la Abadesa, las Discretas y todas las coristas solemnemente profesas de la Comunidad. Todos los cargos se renuevan en dicho período, pero se permite la reelección.

Art. $17^{\circ}$. Los demás Capítulos, para tratar otros asuntos de menor importancia, se reúnen cada mes, asistiendo la Abadesa, como Presidente y las Discretas.

Hispania Sacra, LXIV, Extra I, enero-junio 2012, 179-203, e-ISSN: 1988-4265, doi: 10.3989/hs.2012.029 
Art. 18 ${ }^{\circ}$. Vacante el cargo de Abadesa de la Comunidad, automáticamente la sustituye interinamente en el régimen de la Comunidad, la Vicaria o primera Discreta con el título de Presidenta, hasta el próximo Capítulo Conventual.

Art. $19^{\circ}$. La Abadesa y su Discretorio nombran todos los oficios secundarios de la casa y administran sus bienes según las leyes, dando razón a la Comunidad de las liquidaciones, antes de remitirlas al Gobierno Civil o al Ministerio de Justicia.

Art. $20^{\circ}$. La Superiora de la Comunidad, autorizará con su visto bueno, todas las certificaciones exigidas por las leyes y expedidas por la Secretaria sobre las personas y por la Procuradora sobre los bienes y sobre cualquier alteración de los estados del personal y material.

Título IV. Capacidad Jurídica.

Art. $21^{\circ}$. La Comunidad tiene capacidad jurídica para adquirir, enajenar, poseer y administrar toda clase de bienes y derechos, por cualquier título oneroso o gratuito, por actos inter vivos o mortis causa y para ceder, enajenar, vender, arrendar, permutar, pignorar, hipotecar sus bienes o prestar con hipoteca u otra garantía, aceptar o renunciar legados, reclamar intereses, rentas o frutos y en general, ejercer cualquier otro derecho y celebrar toda clase de actos y contratos que las leyes reconozcan a las personas jurídicas y sean necesarios para el mantenimiento de sus miembros, el sostenimiento del culto y el cumplimiento directo de los fines privativos de la Comunidad, expresados en el título III.

Art. $22^{\circ}$. La Procuradora de la Comunidad lleva la administración de la misma y en ella o en otra persona de su confianza podrá delegar la Abadesa con su Consejo, las facultades necesarias para celebrar los actos y contratos a que se refiere el artículo anterior. También podrá delegar todos los derechos y acciones que haya de ejercer ante los Juzgados y Tribunales y ante toda clase de autoridades competentes, tanto en el orden civil como en el económico administrativo y contencioso administrativo, por cualquier concepto que sea.

Art. $23^{\circ}$. La Procuradora o persona delegada, previa la delegación o mandato a que se refiere el artículo anterior, podrá en representación de la Comunidad y de sus miembros, presentarse en todos los actos, juicios y expedientes que interesen a la misma y proseguirlos en todos los trámites, recursos e incidentes hasta su terminación definitiva y así también reclamar y cobrar todas las cantidades que en conceptos de intereses, rentas o frutos correspondan a sus representados, pudiendo firmar los correspondientes recibos, cartas de pago y demás documentos que proceda.

Art. $24^{\circ}$. La gestión económica ordinaria corresponde a la Procuradora de la Comunidad, pero debe ejercitarla a tenor de las leyes y según las normas del Reglamento del régimen interior y sólo mientras dure en el cargo.

Título V. Sostenimiento de Institución.

Art. $25^{\circ}$. Los medios con que la Comunidad cuenta para su sostenimiento en el cumplimiento de sus fines privativos, son todos los permitidos por las leyes y los que los ministerios de la Comunidad produzcan.

Art. $26^{\circ}$. Entre dichos medios económicos se cuentan las rentas o productos de los bienes o valores de la Comunidad, consentidos por las leyes, la limosna y suscripciones voluntarias, los legados y donaciones mortis causa, el trabajo material, espiritual e intelectual y todo el trabajo personal de sus miembros y sus aportaciones al haber social, pero ninguno de los miembros tiene derecho alguno personal sobre los bienes de la Comunidad, sino que todo cuanto tienen es común a todos los individuos, con la única excepción del dominio radical de los bienes patrimoniales y de los dotales durante la vida, que conservan los miembros de la Comunidad, con las demás garantías individuales que la ley civil establece y reconoce.

Art. $27^{\circ}$. Los ingresos de la Comunidad deberán ser aplicados a sus gastos ordinarios, extraordinarios e imprevistos o eventuales, debiendo figurar en los balances del libro oficial de la 
contabilidad y en los generales que cada año se remiten al Gobierno Civil de la provincia y cada trienio al Ministerio de Justicia.

Art. $28^{\circ}$. En consecuencia, ni las religiosas ni sus parientes, herederos o causahabientes, tendrán derecho a reclamar participación alguna de los fondos sociales, salvo en caso de aportaciones o cesiones hechas con la condición de reclamarlas en el caso de abandono de la Comunidad.

Art. $29^{\circ}$. El fondo social será siempre propiedad de la Comunidad y será administrado por el Consejo, según el reglamento de régimen interior, que se diere la misma Comunidad.

Título VI. Representación Legal.

Art. $30^{\circ}$. La Superiora de la Comunidad y en su defecto la Vicaria, es su representante legal dentro y fuera de la misma para la defensa de sus derechos y de sus bienes y el ejercicio de sus acciones dentro y de sus bienes y el ejercicio de sus acciones dentro y fuera de juicio en todas las esferas, gubernativa, administrativa y contencioso administrativa, por actos que correspondan a la Corporación o a sus miembros como personas jurídicas o socios de la Comunidad.

Art. $31^{\circ}$. Para acreditar la representación bastará el testimonio del acuerdo del Consejo, refrendado por la Secretaria de la Comunidad. Por acuerdo de Consejo podrá la Superiora delegar su representación para determinados negocios a otra persona de su confianza, religiosa o seglar. Queda a salvo lo dispuesto en el artículo 23 sobre la Procuradora.

Título VII. Reglamento de Régimen Interior.

Art. $32^{\circ}$. Reconstituida la Comunidad conforme a los presentes Estatutos ordenará libremente su régimen interior.

Art. $33^{\circ}$. El Reglamento de régimen interior de la Comunidad, una vez aceptado por la misma, obligará a todos sus miembros en lo que concierne al gobierno de las personas como en la administración de los bienes, aunque sin otra trascendencia jurídica que la compatible con las leyes.

Título VIII. Disolución de la Sociedad.

Art. $34^{\circ}$. La Comunidad puede disolverse por Decreto de los Superiores con el Consejo y anuencia de la Autoridad eclesiástica.

Art. $35^{\circ}$. Los bienes que poseyere la Comunidad al disolverse, se distribuirán en la forma que determine el Reglamento de régimen interior y en su defecto se repartirán en partes iguales entre todos sus miembros.

Art. $36^{\circ}$. Si fuere restaurada la Comunidad suspensa o disuelta temporalmente, volverán a la misma los bienes y derechos que la correspondían en el estado en que se encuentren al simple requerimiento de la última Superiora o de la nueva elegida por la Comunidad.

En Villafranca del Bierzo a 26 de agosto de 1933.

\subsection{3.- Convento de Valdemoro}

En 1610 y a iniciativa de Francisco Gómez de Sandoval y Rojas, duque de Lerma, cuatro religiosas de las Descalzas Reales se trasladan a la villa de Valdemoro: Sor Francisca de Jesús, abadesa; Sor Juana Bautista, Sor Ana Víctor y Sor Isabel de la Visitación. ${ }^{48}$

${ }^{48}$ AGP, Patronatos, Descalzas Reales, Caja. 16, Exp. 14. "En la Crónica de la Provincia de Castilla de la Regular Observancia de N. P. San Francisco escrita por el Padre Fray Diego Hurtado, se hallan las noticias siguientes concernientes a la fundación del Convento de la Encarnación de Franciscas Descalzas de la Villa de Valdemoro". 
Tras su solicitud de inscripción se le asigna el número 1.526 siéndoles comunicada la misma en 20 de febrero de $1935 .{ }^{49}$ En el año de la solicitud la abadesa era $D^{a}$ María Paz Gaullés Chocarro, su composición era:

Religiosas Profesas:

- María Paz Gallués Chocarros, natural de Aibar (Navarra). Abadesa

- Isabel Florón Muñoz, natural de la Mata (Teruel). Vicaria Consejera.

- Julita Díez Blanco, natural de la Mata (León). Consejera.

- Concepción Isaba Armañanzas, natural de Estella (Navarra). Consejera.

- María Cilveti Goldaraz, natural de Biurren (Navarra). Consejera.

- María Isabel Alejandrina, natural de Calaceite (Teruel). Secretaria.

- Virginia Bartolomé Santos, natural de Madrid. Procuradora.

- Vicenta Cruz Cruz, natural de Villamayor (Cuenca). Religiosa Profesa.

- Ramona Pérez González, natural de Valderaduey (León). Religiosa Profesa.

- Elisea Castro Anguez, natural de Madrid. Religiosa Profesa.

- Estrella Carrasco Arranz, natural de Santisteban (Jaén). Religiosa Profesa.

- Carmen Ruano Busquets, natural de Madrid. Religiosa Profesa.

- Saturnina Blanco Fernández, natural de Madrid. Religiosa Profesa.

- Enriqueta Nonvela Ramos, natural de Madrid. Religiosa Profesa.

- Feliciano Pedro de Pedro, natural de Peralejo (Soria). Religiosa Profesa.

Religiosas Legas.

- Margarita Santamaría Parraza, natural de Oduña (Vizcaya). Religiosa Profesa.

- Sotera Gorraiz Larrea, natural de Artajona (Navarra). Religiosa Profesa.

- Germana de Vicente Iriarte, natural de Ustes (Navarra). Religiosa Profesa.

- Benedicto Robles Rodríguez, natural de Almanza (León). Religiosa Profesa.

- Eulalia del Amparo García, natural de León. Religiosa Profesa.

La Comunidad no poseía por sí misma, ni por persona interpuesta más bienes inmuebles, valores mobiliarios, ni otra clase de objetos preciosos que los siguientes:

- Finca rústica denominada del Hospital, sita en el término municipal de Valdemoro, de nueve fanegas, equivalente a cinco hectáreas, sesenta y ocho áreas ochenta y ocho centiáreas, que se adquirió por compra a $\mathrm{D}^{\mathrm{a}}$ María Martín Ostolasa, con renta de noventa pesetas anuales.

- Finca rústica denominada Fuente Vieja del Arca, en el término de Valdemoro, de caber dos fanegas, once celemines y seis estadales, adquirida por compra a $\mathrm{D}^{\mathrm{a}}$ Juliana de la Calle Hernández, con renta de veinte pesetas anuales.

- Iglesia situada en la plaza de las Monjas, mide veinticinco metros de largo por siete de ancho, destinada al culto católico y adherida al Convento donde reside la Comunidad.

Valores mobiliarios no tiene y solo poseen los objetos ordinarios para el culto, pues no tienen ninguno precioso o que sea de gran valor.

En el libro de contabilidad figuran las aportaciones a la Comunidad propiamente dichas de las dotes de algunas religiosas, o sea, nueve mil pesetas en Títulos de Deuda, cuyo dominio conserva cada

${ }^{49}$ AGMJ. Eclesiástico, Leg. 128, Exp. 1.562. Expediente de la Congregación de Religiosas Franciscanas Clarisas de Valdemoro (Madrid).

Hispania Sacra, LXIV, Extra I, enero-junio 2012, 179-203, e-ISSN: 1988-4265, doi: 10.3989/hs.2012.029 
una de ellas, más dieciocho acciones del Banco de España de quinientas pesetas cada una pagando los derechos del Estado. También figura en dicho libro una fundación benéfica, valor de veintidós mil pesetas, en Títulos de la Deuda con la obligación de aplicar con los réditos veintitrés misas mensuales de 250 pesetas. Por concepto de equipo, cada religiosa trajo la ropa necesaria para su uso, valorada de 50 a 65 pesetas y después la Comunidad ha seguido sufragándoles los gastos a cada una de vestidos, comida y médico.

En cuanto a los estatutos, remitimos a los de las Descalzas Reales por ser los mismos.

\section{Convento de Chinchón}

En 1593 los Condes de Chinchón (Diego Fernández de Cabrera y Bobadilla e Inés Pacheco) inician las obras del futuro convento. Dicha fábrica se tuvo que suspender y será el nieto de los condes, Francisco Fernández de Cabrera y Bobadilla (Conde de Chinchón) quien reanude las obras, finalizadas en $1653 .^{50}$

Se le asignó el número 1.496 tras su solicitud de inscripción en el registro especial del Ministerio de Justicia, ${ }^{51}$ comunicándoseles la misma el 1 de febrero de 1935. En la fecha de la solicitud la abadesa era $\mathrm{D}^{\mathrm{a}}$ María del Sagrario Abella González siendo el resto de religiosas:

Religiosas Profesas Coristas.

- Sor María del Sagrario Abella González, abadesa, natural de Lillo (León).

- Sor María Paz Jtoiz Alemán, vicaria, natural de Orizcain (Navarra)

- Sor Angeles González Parra, maestra de novicias, natural de Alcalá del Jucar (Albacete).

- Sor Lourdes Fernández Abella, tercera discreta, natural de Chano (León).

- Sor María Fernández López, cuarta discreta, natural de Chinchón (Madrid).

- Sor Sacramento Ortega Martín, sin cargo, natural de Mocejón (Toledo).

- Sor Concepción Rocasin, sin cargo, natural de Madrid.

- Sor Francisca Bendicho Rubio, sin cargo, natural de Chinchón (Madrid).

- Sor Clara Manera, sin cargo, natural de Burgos.

- Sor Emilia Jubera Herreros, sin cargo, natural de Villaconejos (Madrid).

- Sor Teresita Travadela Alvarez, secretaria, natural de Manzaneda (León).

- Sor Esperanza Pérez Martínez, sin cargo, natural de San Cristóbal (León).

- Sor Mercedes Pérez Pérez, sin cargo, natural de San Cristóbal (León).

Religiosas Profesas Legas.

- Sor Purificación Pérez López, natural de San Cristóbal (León)

- Sor Trinidad Pérez López, natural de San Cristóbal (León)

Religiosas Novicias Coristas.

- Sor Mariana López Guerrero, natural de Villar del Infantado (Cuenca).

- Sor Margarita Travadela Alvarez, natural de Manzaneda (León).

${ }^{50}$ AGP, Patronatos, Descalzas Reales, Caja. 16, Exp. 17. Convento de la Concepción de Religiosas Franciscas Clarisas Descalzas de la villa de Chinchón. S.f.

${ }^{51}$ AGMJ. Eclesiástico, Leg. 121, Exp. 1.496. 
La Comunidad no poseía por sí misma, ni por persona interpuesta más bienes inmuebles, valores mobiliarios, ni otra clase de objetos preciosos que los siguientes:

- Finca urbana sita en la calle Alfonso XIII, de dieciséis mil metros cuadrados, adquirida por título de donación de los Excmo. Sres. Condes de Chinchón, registrada en propiedad al folio ciento setenta y dos, del tomo mil trescientos dieciocho del archivo, libro ciento noventa y cinco, según se ha acreditado con la certificación del Registro, en estado de conservación ruinoso, tasado su capital en pesetas cincuenta mil (en el Registro).

- Esta Comunidad no posee ningún mueble, ni objetos de valor histórico ni artístico. Solamente los objetos del culto estrictamente necesarios y estos pobres y sencillos.

- En los libros de contabilidad, inventarios y balances de la Comunidad, no figuran aportaciones a la Comunidad propiamente dichas del patrimonio de las religiosas, ni de sus dotes, cuyo dominio radica, conserva cada una. Ni su equipo aporta nada a la Comunidad (por ser solo las ropas de propio uso que no pueden valorarse). Es de advertir que la Comunidad se sufraga todos los gastos de instrucción y alimentación, como miembros de la misma, aun los extraordinarios.

Sus estatutos:

Estatutos de la Comunidad de Monjas Clarisas Franciscanas establecida en la ciudad de Chinchón, provincia de Madrid.

Título I. Constitución, Denominación y Domicilio.

Art. $1^{\circ}$. Al amparo de la Constitución y de la Ley especial de Confesiones y Congregaciones Religiosas se reconstituye en la Ciudad (Villa) de Chinchón, provincia de Madrid, una Comunidad de la Orden, aprobada por el Sumo Pontífice Inocencio IV, el día 9 de agosto de 1253.

Art. $2^{\circ}$. Para todos los efectos legales, la Comunidad se regirá por los presentes Estatutos y con arreglo a las leyes vigentes.

Art. $3^{\circ}$. La Comunidad al reconstituirse tiene su domicilio social en la calle de Alfonso XIII y aquí celebrará sus reuniones de orden interno.

Título II. Fines de la Comunidad y de su Orden.

Art. $4^{\circ}$. El fin de la Comunidad es el general de la Orden, o sea la santificación de las Religiosas mediante la guarda del Evangelio y la observancia de los votos de pobreza, castidad y obediencia, realizado en esta región.

Art. $5^{\circ}$. Esta Comunidad que tiene por objeto principal el culto divino, no excluye las obras de caridad y de apostolado compatibles con esta sagrada obligación, ni mucho menos la formación integral de sus miembros ni la enseñanza oportuna de la religión, ni otras obras de misericordia, espirituales y corporales, según sus recursos, ni la formación de Comunidades filiales en España y en el extranjero.

Art. $6^{\circ}$. Esta Comunidad admite (o no) residencias, internados, pensionados y externados para la educación extraacadémica, religiosa y doméstica o para simple retiro de las personas, para fines morales, sociales, o profesionales, excluida toda mira de lucro, aunque se satisfacen todas las contribuciones correspondientes.

Art. $7^{\circ}$. Excluyese de los fines sociales de la Comunidad, toda actividad política y la explotación comercial, agrícola o docente en la colectividad.

Título III. Miembros y Gobierno de la Comunidad y de la Orden.

Art. $8^{\circ}$. La Orden se compone de provincias canónicas.

Hispania Sacra, LXIV, Extra I, enero-junio 2012, 179-203, e-ISSN: 1988-4265, doi: 10.3989/hs.2012.029 
Art. $9^{\circ}$. Las provincias canónicas se componen a su vez de Comunidades llamadas monasterios.

Art. $10^{\circ}$. Las Comunidades constan de religiosas de coro y de obediencia, correspondiendo a las coristas los cargos y a las legas los oficios y quehaceres domésticos sin salario unas y otras.

Art. $11^{\circ}$. La entrada y salida de las socias se ajusta a las normas de los sagrados cánones, siendo necesaria la admisión de los sujetos por parte de los superiores, la dispensa para la salida sin votos y las formalidades establecidas para las expulsiones. Queda a la conciencia de los individuos la permanencia en la Comunidad.

Art. $12^{\circ}$. Los miembros conservan todos sus derechos civiles y políticos, aún después de la profesión religiosa, y por tanto la propiedad de sus bienes patrimoniales y haber hereditario y la capacidad de adquirir para sí otros de cualquier clase que sean, salvo lo dispuesto en las leyes y en el reglamento de régimen interior.

Art. $13^{\circ}$. La presente Comunidad es independiente en su régimen interno.

Art. $14^{\circ}$. La Comunidad se gobierna y administra legalmente por la Abadesa y su Discretorio.

Art. $15^{\circ}$. El Discretorio o gobierno local de la Comunidad se compone de la Abadesa, como Presidente, cuatro Consultoras o Discretas, de Secretaria y Ecónoma o Procuradora, pero el cargo de Consultora no es incompatible con el de Secretaria ni de Procuradora.

Art. $16^{\circ}$. Los cargos de Abadesa y Discretas se proveen por mayoría absoluta de votos de sus individuos coristas de la Comunidad, los otros por la Abadesa y Discretas.

Art. $17^{\circ}$. El Gobierno de la Comunidad respeta y acata la jurisdicción del Ordinario diocesano.

Art. $18^{\circ}$. La Comunidad trata en Capítulo los asuntos económicos y administrativos de importancia para la casa, pudiendo dictar los reglamentos oportunos para su régimen interior y el bien espiritual y material de sus miembros.

Art. $19^{\circ}$. El Capítulo conventual para las elecciones se reúne cada tres años para tratar de la renovación de los cargos de la Comunidad. En dicho Capítulo tienen voz y voto la Abadesa, las Discretas y todas las coristas solemnemente profesas de la Comunidad. Todos los cargos se renuevan en dicho período, pero se permite la reelección.

Art. $20^{\circ}$. Los demás Capítulos, para tratar otros asuntos de menor importancia, se reúnen cada mes, asistiendo la Abadesa, como Presidente y las Discretas.

Art. $21^{\circ}$. Vacante el cargo de Abadesa de la Comunidad, automáticamente la sustituye interinamente en el régimen de la Comunidad, la Vicaria o primera Discreta con el título de Presidenta, hasta el próximo Capítulo Conventual.

Art. $22^{\circ}$. No ha Capítulos intermedios, pasada la mitad del período señalado.

Art. $23^{\circ}$. La Abadesa y su Discretorio nombran todos los oficios secundarios de la casa y administran sus bienes según las leyes, dando razón a la Comunidad de las liquidaciones mensuales o trimestrales, antes de remitirlas al Gobierno Civil o al Ministerio de Justicia.

Art. $24^{\circ}$. La Superiora de la Comunidad, autorizará con su visto bueno, todas las certificaciones exigidas por las leyes y expedidas por la Secretaria sobre las personas y por la Procuradora sobre los bienes y sobre cualquier alteración de los estados del personal y material.

Título IV. Capacidad Jurídica.

Art. $25^{\circ}$. La Comunidad tiene capacidad jurídica para adquirir, enajenar, poseer y administrar toda clase de bienes y derechos, por cualquier título oneroso o gratuito, por actos inter vivos o mortis causa y para ceder, enajenar, vender, arrendar, permutar, pignorar, hipotecar sus bienes o prestar con hipoteca u otra garantía, aceptar o renunciar legados, reclamar intereses, rentas o frutos y en general, ejercer cualquier otro derecho y celebrar toda clase de actos y contratos que las leyes reconozcan a las personas jurídicas y sean necesarios para el mantenimiento de sus miembros, el sostenimiento del culto y el cumplimiento directo de los fines privativos de la Comunidad, expresados en el título III. 
Art. 26 $6^{\circ}$. La Procuradora de la Comunidad lleva la administración de la misma y en ella o en otra persona de su confianza podrá el Inspector superior con su Consejo, las facultades necesarias para celebrar los actos y contratos a que se refiere el artículo anterior. También podrá delegar todos los derechos y acciones que haya de ejercer ante los Juzgados y Tribunales y ante toda clase de autoridades competentes, tanto en el orden civil como en el económico administrativo y contencioso administrativo, por cualquier concepto que sea.

Art. $27^{\circ}$. La Procuradora o persona delegada, previa la delegación o mandato a que se refiere el artículo anterior, podrá en representación de la Comunidad y de sus miembros, presentarse en todos los actos, juicios y expedientes que interesen a la misma y proseguirlos en todos los trámites, recursos e incidentes hasta su terminación definitiva y así también reclamar y cobrar todas las cantidades que en conceptos de intereses, rentas o frutos correspondan a sus representados, pudiendo firmar los correspondientes recibos, cartas de pago y demás documentos que proceda.

Art. $28^{\circ}$. La gestión económica ordinaria corresponde a la Procuradora de la Comunidad, pero debe ejercitarla a tenor de las leyes y según las normas del Reglamento del régimen interior y sólo mientras dure en el cargo.

Título V. Sostenimiento de la Institución.

Art. $29^{\circ}$. Los medios con que la Comunidad cuenta para su sostenimiento en el cumplimiento de sus fines privativos, son todos los permitidos por las leyes y los que los ministerios de la Comunidad produzcan.

Art. $30^{\circ}$. Entre dichos medios económicos, la limosna y suscripciones voluntarias, los legados y donaciones mortis causa, el trabajo material, espiritual e intelectual y todo el trabajo personal de sus miembros y sus aportaciones al haber social, pero ninguno de los miembros tiene derecho a alguno personal sobre los bienes de la Comunidad, sino que todo cuanto tienen es común a todos los individuos, con la única excepción del dominio radical de los bienes patrimoniales y de los dotales durante la vida, que conservan los miembros de la Comunidad, como las demás garantías individuales que la Ley civil establece y reconoce.

Art. $31^{\circ}$. Los ingresos de la Comunidad deberán ser aplicados a sus gastos ordinarios, extraordinarios e imprevistos o eventuales, debiendo figurar en los balances mensuales o trimestrales del libro oficial de la contabilidad y en los balances generales que cada año se remiten al Gobierno civil de la provincia y cada trienio al Ministerio de Justicia.

Art. $32^{\circ}$. En consecuencia, ni las religiosas, ni sus parientes, herederos o causahabientes, tendrán derecho a reclamar participación alguna de los fondos sociales, salvo en caso de aportaciones o cesiones hechas con la condición de reclamarlas en el caso de abandono de la Comunidad.

Art. $33^{\circ}$. El fondo social será siempre propiedad de la Comunidad y será administrado por su Procuradora, según el reglamento del régimen interior que se diere la misma Comunidad.

Título VI. Representación Legal.

Art. $34^{\circ}$. La Superiora de la Comunidad y en su defecto la Vicaria, es su representante legal dentro y fuera de la misma para la defensa de sus derechos y de sus bienes y el ejercicio de sus acciones dentro y de sus bienes y el ejercicio de sus acciones dentro y fuera de juicio en todas las esferas, gubernativa, administrativa y contencioso administrativa, por actos que correspondan a la Corporación o a sus miembros como personas jurídicas o socios de la Comunidad.

Art. $35^{\circ}$. Para acreditar la representación bastará el testimonio del acuerdo del Consejo, refrendado por la Secretaria de la Comunidad. Por acuerdo de Consejo podrá la Superiora delegar su representación para determinados negocios a otra persona de su confianza, religiosa o seglar. Queda a salvo lo dispuesto en el artículo 27 sobre la Procuradora. 
Título VII. Reglamento de Régimen Interior.

Art. $36^{\circ}$. Reconstituida la Comunidad conforme a los presentes Estatutos ordenará libremente su régimen interior.

Art. $33^{\circ}$. El Reglamento de régimen interior de la Comunidad, una vez aceptado por la misma, obligará a todos sus miembros en lo que concierne al gobierno de las personas como en la administración de los bienes, aunque sin otra trascendencia jurídica que la compatible con las leyes.

Título VIII. Disolución de la Sociedad.

Art. $34^{\circ}$. La Comunidad puede disolverse por Decreto de los Superiores con el Consejo y anuencia del Ordinario diocesano.

Art. $35^{\circ}$. Los bienes que poseyere la Comunidad al disolverse, se distribuirán en la forma que determine el Reglamento de régimen interior y en su defecto se repartirán en partes iguales entre todos sus miembros.

Art. $36^{\circ}$. Si fuere restaurada la Comunidad suspensa o disuelta temporalmente, volverán a la misma los bienes y derechos que la correspondían en el estado en que se encuentren al simple requerimiento de la última Superiora o de la nueva elegida por la Comunidad.

En Chinchón día 23 de agosto de 1933.”.

\section{Convento de Abiego (Huesca)}

El 7 de abril de 1913 salieron de las Descalzas Reales, cuatro religiosas que habían sido designadas para fundar la comunidad de Abiego: Sor María del Consuelo que iba nombrada como abadesa, Sor María de la Concepción con el cargo de Vicaria y maestra de novicias, Sor María Presentación (portera y tornera) y Sor María Patrocinio como enfermera y segunda sacristana. ${ }^{52}$

Inscritas con el número 1.053 les fue comunicada la misma el 2 de mayo de $1934 .^{53}$ En estos momentos la abadesa era $\mathrm{D}^{\mathrm{a}}$ Guadalupe Claver (sustituida por Sor Joaquina Alfara el 28 de noviembre de 1935) siendo el resto de las religiosas:

- María Guadalupe Claver, Superiora, natural de Abiego (Huesca).

- María Consuelo Monclús, Vicaria y Consejera, natural de Abiego (Huesca).

- María Presentación de Medina, Consejera Secretaria y Ecónoma, natural de Madrid.

- María Angeles Lecumberri, Consejera y Tornera, natural de Pamplona.

- María Joaquina Alfaro, Consejera y $2^{a}$ Tornera, natural de Bespén (Huesca).

- María Patrocinio Jordán, sin cargo, natural de Abiego (Huesca).

- María Purificación Monclús, sin cargo, natural de Abiego (Huesca)

- María Rosario Domper, sin cargo, natural de Salas Altas (Huesca).

- María del Carmen Domper, sin cargo, natural de Salas Altas (Huesca).

- María del Milagro Lasierra, sin cargo, natural de Abiego (Huesca).

- María Margarita Soret, sin cargo, natural de Villafranca de Navarra.

- María Natividad Monclús, sin cargo, natural de Abiego (Huesca).

- María Francisca Nasarre, sin cargo, natural de Radiquero (Huesca).

- María del Sacramento Panzano, sin cargo, natural de Abiego (Huesca).

- María Josefina Albajar, sin cargo, natural de Abiego (Huesca).

${ }^{52}$ AGP, Patronatos, Descalzas Reales, Caja. 16, Exp. 13. Libro de la fundación, p. 1.

${ }^{53}$ AGMJ. Eclesiástico, Leg. 110, Exp. 1.053. 
- María Ana Jordedo, sin cargo, natural de Martije (Galicia).

De acuerdo con una certificación de fecha 18 de agosto de 1933, expedida por la Abadesa, esta Comunidad carecía de bienes inmuebles, valores mobiliarios y objetos preciosos, pues el Convento donde habitan es una cesión de la Mitra de Huesca, a quien pertenece desde el año ochocientos sesenta $\mathrm{y}$ siete y en los libros de contabilidad y balances, figuran las aportaciones hechas a la Comunidad del patrimonio de las religiosas y que asciende a cuarenta y cuatro mil quinientas pesetas (44.500 ptas.) Los estatutos por los que se regía eran los siguientes:

\section{Estatutos}

Artículo $1^{\circ}$. La Comunidad religiosa establecida en el edificio contiguo a la Iglesia de San Joaquín, ha tomado el acuerdo de inscribirse en el Registro especial de las Congregaciones Religiosas, y presenta al efecto en la oficina correspondiente del Ministerio de Justicia, dos ejemplares de los Estatutos por los que se rige, de acuerdo con el art. 25 de la Ley de Confesiones y Congregaciones religiosas de 2 de junio de 1933.

Artículo $2^{\circ}$. Su denominación será Comunidad de Religiosas Franciscanas Clarisas de San Joaquín y su domicilio social, la Casa Convento, propiedad del Obispado de Huesca, situado en la Plaza de San Joaquín, como lo ha sido hasta ahora.

Artículo $3^{\circ}$. El fin de esta Comunidad es el mismo de la Segunda Orden de Franciscanas o Monjas Clarisas, a que pertenece. Y el fin de la Segunda Orden Franciscana consiste en promover la santificación de sus individuos por el cumplimiento de los votos de pobreza, obediencia y castidad, la guarda de la clausura y la vida contemplativa y promover el bien espiritual de los demás cristianos por medio del apostolado, del ejemplo y de la oración. Queda excluida de los fines sociales de esta Comunidad de San Joaquín, la explotación agrícola y toda actividad política, industrial, comercial y docente.

Artículo $4^{\circ}$. Esta Comunidad se gobierna por una Superiora llamada Abadesa y su Consejo, que se compone de cuatro Discretas, una de las cuales hace además de Secretaria y Ecónoma, nombradas por el Capítulo conventual. En ausencia de la Superiora por muerte o enfermedad, hace sus veces la Discreta más antigua.

Artículo $5^{\circ}$. El Discretorio de la Comunidad se reúne en Junta varias veces al año para el examen de cuentas y deliberar sobre asuntos de interés para la misma.

Artículo $6^{\circ}$. La Comunidad se reúne en Capítulo cada tres años, para la renovación de cargos, previa la visita canónica del Monasterio por el Ordinario o su Delegado. En esta Capítulo tienen voz y voto todas las monjas de coro solemnemente profesas. Todos los cargos se renuevan en dicho Capítulo, pero se permite la reelección.

Artículo $7^{\circ}$. La Comunidad tiene capacidad para adquirir, poseer, enajenar y administrar bienes dentro de los límites señalados por la Ley civil y el derecho canónico.

Artículo $8^{\circ}$. Los medios con que esta Comunidad cuenta para realizar sus fines y atender a sus gastos, son los intereses de las aportaciones de sus individuos al ingresar en la Orden. Y los bienes obtenidos de esa manera, entran todos en el acervo común y ningún individuo personalmente puede alegar derecho sobre ellos, sino que continuarán siendo de la Comunidad mientras esta subsista.

Artículo $9^{\circ}$. Si la Comunidad llega a disolverse por cualquier motivo, el Ordinario dispondrá lo que debe hacerse con los bienes de ella.

Abiego a 18 de agosto de 1933".

\section{BIBLIOGRAFÍA}


Asensio Sánchez, M. A. 1999. Proceso secularizador y libertad de enseñanza en el Derecho Histórico español. Málaga: Universidad de Málaga.

García de Armesto, J. 1930. Nuevas Constituciones de la Real Fundación de la Capilla y Monasterio de las Descalzas de Madrid. Madrid: Editado por Senén Martin Díaz.

Muñoz Serrulla, Ma T; Vilacoba Ramos, K Ma, y Sanz de Bremond Mayáns, A. 2008. "Exclaustraciones en las Descalzas Reales: Supervivencia de una Fundación Real en la primera mitad del siglo XX" en Peláez del Rosal, M. (dir., y ed.), El franciscanismo en Andalucía. Exclaustraciones y desamortización de los conventos franciscanos andaluces: 175-196. Córdoba: Córdoba, Asociación Hispánica de Estudios Franciscanos. XIII Curso de Verano sobre "El Franciscanismo en Andalucía” 24-27 de Julio de 2007.

Vilacoba Ramos, K M y Muñoz Serrulla, Ma T. 2009. "Fuentes documentales sobre la Obra benéfica de Doña Juana de Austria: fundaciones principales, particulares y externas de las Descalzas Reales de Madrid", Revista AAM (Asociación de Archiveros de Madrid), 4: 54-67.

Vilacoba Ramos, K M y Muñoz Serrulla, M M $^{\mathrm{a}}$ T. 2010: "Las Religiosas de las Descalzas Reales de Madrid en los siglos XVI-XX: Fuentes archivísticas”, Hispania Sacra, LXII/125: 153.

\section{FUENTES ARCHIVÍSTICAS}

Archivo General del Ministerio de Justicia (AGMJ). Fondo Eclesiástico:

- Leg. 110, Exp. 1.053.

- Leg. 121, Exp. 1.496.

- Leg. 128, Exp. 1.562.

- Leg. 167, Exp. 3.219.

- Leg. 187, Exp. 4.012.

Archivo General de Palacio (AGP). Fondo Patronatos, Descalzas Reales:

- Caja. 13, Exp. 10.

- Caja. 16, Exp. 13.

- Caja. 16, Exp. 14.

- Caja. 16, Exp. 17.

- Leg. 17, Exp. 1.

- Leg. 33, Exp. 1. 